\title{
PERAN PERDANGANGAN ELEKTRONIK TERHADAP KEMAJUAN BISNIS INTERNASIONAL
}

\section{Ramayanti Simanjorang, Nuri Aslami}

Universitas Islam Negeri (UIN) Sumatera Utara, Medan, Indonesia

Email: simanjorang2019@gmail.com,nuriaslami@uinsu.ac.id

\begin{tabular}{ll}
\hline INFO ARTIKEL & ABSTRAK \\
\hline Diterima & Pada saat ini dunia telah memasuki revolusi industri 4.0, dimana semua \\
12 Desember 2021 & aktivitas kehidupan berbasis digital. Kemajuan dunia teknologi saat ini \\
Direvisi & mewajibkan internet sebagai salah satu alat komunikasi, pertukaran data, \\
19 Desember 2021 & dan media pencari informasi yang banyak diminati oleh setiap kalangan \\
Disetujui & terutama generasi milenial. Dan juga saat ini transaksi bisnis tidak jarang \\
2 Januari 2022 & kita temui sudah melalui digital, contohnya Shoope, Lazada, Bukalapak, \\
\hline Kata Kunci: & dan lain-lain. Dan tanpa terkecuali bisnis internasional juga telah \\
Perdagangan & melakukan transaksi melalui digital. Penelitian bertujuan untuk \\
elektronik; Bisnis & mengetahui peran perdangangan elektronik terhadap kemajuan bisnis \\
internasional & internasional. Metode yang peneliti gunakan dalam penelitian ini ialah \\
& metode penelitian kualitatif, dengan Studi dokumen atau teks merupakan \\
& kajian yang menitik beratkan pada analisis atau interpretasi bahan \\
& tertulis berdasarkan konteksnya. Bahan bisa berupa catatan yang \\
& terpublikasikan, buku teks, surat kabar, majalah, surat-surat, film, catatan \\
& harian, naskah, artikel, dan sejenisnya.
\end{tabular}

\section{ABSTRACT}

At this time the world has entered the industrial revolution 4.0, where all life activities are digital based. The advancement of the world of technology today requires the internet as a means of communication, data exchange, and information seeking media which is in great demand by every group, especially the millennial generation. And also nowadays, we often encounter business transactions via digital, for example Shoppe, Lazada, Bukalapak, and others. And without exception, international businesses have also made transactions via digital. This study aims to determine the role of digital trade on the progress of international business. The method that the researcher uses in this research is a qualitative research method, with document or text studies being a study Keywords: $\quad$ that focuses on the analysis or interpretation of written material based on Elektronic trade; its context. Materials can be in the form of published notes, textbooks, International newspapers, magazines, letters, films, diaries, manuscripts, articles, and business the like.

\section{Pendahuluan}

Era baru digital marketing telah masuk ke dalam praktik kehidupan masyarakat modern.Pasar-pasar baru dan produsenprodusen baru telah tercipta dengan menggunakan internet (Sholihin, 2019). Pemanfaatan internet membuat jaringan masyarakat dunia tersatukan dalam apa yang disebut satu kampung global (Iswari et al., 2021). Dengan pengguna yang makin luas

$\begin{array}{ll}\text { How to cite: } & \text { Simanjorang, Ramayanti, Nuri Aslami (2022). Peran Perdangangan Elektronik Terhadap Kemajuan } \\ & \text { Bisnis Internasional, Action Research Literate, 6(1). } \\ \text { E-ISSN: } & 2721-2769 \\ \text { Published by: } & \text { Ridwan Institute }\end{array}$


dan global meliputi berbagai bangsa di seluruh dunia, setiap masyarakat telah menjadi obyek pasar bagi para produsen sekaligus menjadi pelaku pasar itu sendiri.

Munculnya electronic commerce atau sering kita kenal istilah ini dengan perdagangan elektronik membawa suatu perubahan struktural yang sangat besar yang mempengaruhi organisasi perusahaan, perilaku konsumen, perekonomian dan seluruh aspek aktivitas manusia pada skala global (Shaw et al., 2012).

Perdagangan elektronik tumbuh dan berkembang dengan pesat pada seluruh aspek dunia bisnis, dan hal ini diyakini akan merubah secara drastis bukan hanya dalam lingkungan bisnis tapi juga masyarakat dan perekonomian secara luas (Sari et al., 2020). Perdagangan elektronik tidak hanya akan merubah cara perusahaan menjalankan bisnisnya tapi juga akan mentransformasi "inter- dan intra-organisasi perusahaan". Secara lebih spesifik, perkembangan internet telah mewakili perubahan yang fundamental pada jaringan telekomunikasi (Purnastuti, 2004).

Perusahaan komersial internet dan jaringan generasi masa depan harus dapat beradaptasi dengan lingkungan baru ini. Menurut (Schwab, 2019) Pemahaman yang luas mengenai internet dan segala efek dan konsekuensinya akan memberikan sumbangan yang sangat berarti untuk mengembangkan strategi bisnis yang tepat. Di sisi lain pembuat kebijakan dan legislator perlu memperluas cakrawala pengetahuan mereka akan perdagangan elektronik sehingga dapat tercipta sektor ekonomi yang praktis dan nyata melalui perumusan aturan dan kebijakan yang layak.

\section{Metode Penelitian}

Metode yang peneliti gunakan dalam penelitian ini ialah metode penelitian kualitatif, dengan Studi dokumen atau teks. Menurut (Nilamsari, 2014) studi dokumen merupakan kajian yang menitik beratkan pada analisis atau interpretasi bahan tertulis berdasarkan konteksnya. Bahan bisa berupa catatan yang terpublikasikan, buku teks, surat kabar, majalah, surat-surat, film, catatan harian, naskah, artikel, dan sejenisnya (Komariah, 2014).

\section{Hasil dan Pembahasan}

Perdagangan digital merupakan salah satu sektor yang harus terus dikembangkan dan dikelola dengan baik. Untuk itu, pemerintah harus menciptakan ekosistem ecommerce yang adil dan bermanfaat.

Zaman sekarang ini adalah zaman modern, hampir semua hal bisa dilakukan dari rumah, dari mulai membayar semua tagihan baik berupa tagihan telepon, internet, tv berbayar, listrik, pam dan lain-lain, cukup dengan menggunakan m-banking, dan semua bisa dilakukan dengan cara online. Kita tidak dapat memungkiri pentingnya teknologi informasi dalam kehidupan kita. Teknologi informasi (TI) telah menjadi bagian yang sangat penting dalam setiap rencana bisnis. Hampir dari seluruh perusahaan baik skala besar maupun kecil menggunakan Teknologi Informasi, sebagai salah satu aktifitas yang sangat dibutuhkan untuk memberikan peningkatan terhadap layanan bisnis yang mereka kelola.

Teknologi Informasi telah banyak digunakan untuk mendukung proses bisnis yang terjadi pada perusahaan, baik bidang ekonomi maupun perbankan. Dengan hadirnya aplikasi-aplikasi dan layanan ebussiness, e-commerce, e-banking dan lainlain. Kebutuhan efisiensi waktu dan biaya menyebabkan setiap pelaku bisnis merasa perlu menerapkan teknologi informasi dalam lingkungan kerja. Penerapan Teknologi Informasi menyebabkan perubahan pada pola kebiasaan kerja. Misalnya penerapan Enterprice Resource Planning (ERP).

Dalam dunia bisnis peranan Teknologi Informasi dimanfaatkan untuk perdagangan 
secara elektronik atau dikenal sebagai ECommerce (e-dagang) atau perdagangan elektronik (Ghifari, 2021). E-Commerce adalah perdagangan menggunakan jaringan komunikasi internet. E-commerce merupakan bagian dari e-business, di mana cakupan ebusiness lebih luas, tidak hanya sekedar perniagaan tetapi mencakup juga pengkolaborasian mitra bisnis, pelayanan nasabah, lowongan pekerjaan dan lain-lain. Selain teknologi jaringan www, e-dagang juga memerlukan teknologi basis data atau pangkalan data (databases), e-surat atau surat elektronik (e-mail), dan bentuk teknologi non komputer yang lain seperti halnya sistem pengiriman barang, dan alat pembayaran untuk e-dagang ini.

Menurut (Savetlana \& Andriyanto, 2012) Laporan McKinsey Global Institute (MGI) menjelaskan bahwa Era baru "Persaingan global" memungkinkan perusahaan mencapai pasar internasional dengan model bisnis yang kurang padat modal, hal tersebut berdampak pada risiko dan tantangan bagi berbagai negara dalam memformulasikan sebuah kebijakan baru untuk mengikuti kecepatan perkembangan fenomena global ini. Ekonomi digital merubah ekonomi global, memungkinkan industri kecil menjadi industri multinasional mikro dengan elastisitas dan dinamika yang mereka miliki. Hal ini memberi kesempatan yang lebih tinggi bagi para pemula untuk terlahir secara global, digitalisasi mendorong persaingan karena memungkinkan model bisnis yang inovatif dan memungkinkan perusahaan untuk meningkat dengan cepat. Puluhan juta perusahaan kecil dan menengah di seluruh dunia telah berubah menjadi eksportir dan bergabung dengan pasar ecommerce, dan bisa bersaing dengan perusahaan multinasional terbesar

\section{Kesimpulan}

Dari pembahasan diatas peneliti menyimpulkan bahwa perdagangan elektronik sangat berperan penting terhadap kemajuan bisnis internasional, karena zaman sekarang segala sesuatu berhubungan dengan IPTEK. Contohnya sekarang berbelanja bisa melalui online tidak perlu ribet lagi. Maka dari itu negara Indonesia melakukan inovasi guna memajukan perekonomian negara. Para generasi milenial sangat dituntut agar kreatif supaya berkurang nya penganguran diusia produktif.

Namun ketika Negara melalui pemanfaatan teknologi mampu merubah khayalan dan impian manusia menjadi sebuah inovasi dengan menghasilkan banyak ragam dan system operasi produk barang dan jasa yang kompleks, maka hal itu akan meningkatkan globalisasi dan kemajuan teknologi, berdampak pada banyaknya masalah yang akan dihadapi. Karena itu teknologi selalu merujuk pada sebuah "pertimbangan" melalui penerapan pengetahuan tentang sistem kompleks yang berkaitan dengan struktur dan system dinamik (Funke, 2001). Teknologi juga dimanfaatkan untuk membuat prediksi di lingkungan yang kompleks dengan cara melakukan penelitian dan kajian serta expert judgment dari "domain" pengetahuan tertentu. Intinya kita sebagai generasi milineal, generasi yang akan membawa perubahan baik terhadap negara harus selektif dalam memilih perkembangan teknologi.

\section{BIBLIOGRAFI}

Funke, J. (2001). Neue Verfahren zur Erfassung intelligenten Umgangs mit komplexen und dynamischen Anforderungen.Google Scholar

Ghifari, F. I. (2021). Fakhrul Ikhtiar-Peran dan Fungsi E-Bisnis Dalam Bisnis Digital. Google Scholar

Iswari, I., Fahmi, R. S., Indra, B. P., \& Linggar, M. S. (2021). Pengembangan Pemasaran Desa Batik Jetis Di Era Digital. Prapanca: Jurnal Abdimas, 
1(1), 60-68. Google Scholar

Komariah, A. (2014). Metodologi penelitian kualitatif. Google Scholar

Nilamsari, N. (2014). Memahami studi dokumen dalam penelitian kualitatif. WACANA: Jurnal Ilmiah Ilmu Komunikasi, 13(2), 177-181. Google Scholar

Purnastuti, L. (2004). Perdagangan Elektronik: Suatu Bentuk Pasar Baru yang Menjanjikan? Jurnal Ekonomi Dan Pendidikan, 1(1). Google Scholar

Sari, D. C., Effendy, F., Sudarso, A., Abdillah, L. A., Fadhillah, Y., Fajrillah, F., Setiawan, Y. B., Simarmata, J., Watrianthos, R., \& Jamaludin, J. (2020). Perdagangan Elektronik: Berjualan di
Internet. Yayasan Kita Menulis. Google Scholar

Savetlana, S., \& Andriyanto, A. (2012). SifatSifat Mekanik Komposit Serat TKKSPoliester. Mecahnical, 3(1), 45-50. Google Scholar

Schwab, K. (2019). Revolusi Industri Keempat.

Gramedia Pustaka Utama. Google Scholar

Shaw, M., Blanning, R., Strader, T., \& Whinston, A. (2012). Handbook on electronic commerce. Springer Science \& Business Media. Google Scholar

Sholihin, R. (2019). Digital marketing di Era 4.0. Anak Hebat Indonesia. Google Scholar

\section{Copyright holder :}

Ramayanti Simanjorang, Nuri Aslami (2022).

First publication right :

Action Research Literate

This article is licensed under:

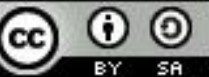

